\title{
Model Zmijewski X-Score Untuk Memprediksi Financial Distress Pada Perusahaan Go Publik Sub Sektor Otomotif Dan Komponen
}

\author{
Suhesti Ningsih*, Febrina Fitri Permatasari \\ Sekolah Tinggi Ilmu Ekonomi AAS Surakarta \\ *Email korenpondensi: hesti.hegi@gmail.com
}

\begin{abstract}
Abstrak
Penelitian ini bertujuan untuk memprediksi financial distress menggunakan model Zmijewiski X-Score pada perusahaan go publik sub sektor otomotif dan komponen. Dimana kondisinya pada sektor otomotif dan komponen Indonesia masih mengimpor sekitar $80 \%$. Jenis penelitian yang digunakan adalah penelitian deskriptif dengan pendekatan studi kasus. Hasil analisis menggunakan model Zmejiwiski X-Score menunjukkan bahwa pada tahun 2012 dan tahun 2014 tidak ada perusahaan yang diprediksi dalam kondisi financial distress. Sementara Perusahaan yang mempunyai nilai X-Score >0 atau positif dengan demikian diprediksi dalam kondisi financial distress pada tahun 2013 adalah BOLT dengan nilai 0,84, tahun 2015 dengan nilai 0,04 yaitu IMAS dan tahun2016 yaitu IMAS sebesar 0,45 dan LPIN dengan nilai 1,25, sedangkan perusahann lainnya dalam kondisi keuangan yang sehat. Dari hasil analisis metode X-Score menunjukkan bahwa selama 5 tahun nilai rata-ratanya dibawah $O$ atau negatif maka berarti kondisi keuangan semua perusahaan dalam kondisi sehat.
\end{abstract}

Kata kunci: Financial Distress, Zmijewksi, X-Score

Saran sitasi: Ningsih, S., \& Permatasari, F. (2019). Model Zmijewski X-Score Untuk Memprediksi Financial Distress Pada Perusahaan Go Publik Sub Sektor Otomotif Dan Komponen. Jurnal Akuntansi dan Pajak, 19(2), 134-140. doi:http://dx.doi.org/10.29040/jap.v19i2.356

DOI: http://dx.doi.org/10.29040/jap.v19i2.256

\section{Pendahuluan}

Pertumbuhan sektor industri otomotif di Indonesia semakin pesat akan tetapi masih mengalami masalah yang cukup serius dimana bahan baku dan impor komponen otomotif sebagian besar masih impor. Ketua Umum GIAMM, Hamdhani Dzulkarnaen Salim, menyatakan bahwa sebagian besar onderdil kendaraan bermotor di dalam negeri juga masih diproduksi menggunakan bahan baku impor (60\%). Bahan baku ini kebanyakan berasal dari negara nonASEAN, seperti Korea Selatan, Jepang, dan China. Hal ini dapat berakibat jatuhnya harga saham dan melemahnya kurs rupiah serta ketika negara pemasok mengalami bencana alam seperti tsunami di Jepang (Warta Ekonomi, 2018). Akibat dari tingkat suku bunga dan inflasi meningkat tajam serta investasi berkurang maka akan mempengaruhi kesehatan perusahaan, yaitu terjadinya penurunan bahkan berpotensi untuk bangkrut.

Financial distress atau kesulitan keuangan adalah kegagalan perusahaan dalam memenuhi pembayaran kewajibannya, dimana hal itu merupakan awal terjadinya kebangkrutan. Financial Distress dan tanda-tanda awal kebangkrutan dapat diketahui melalui analisis terhadap data yang terdapat dalam laporan keuangan. Menurut Sudana (2011) menyatakan bahwa faktor-faktor penyebab terjadinya financial distress adalah 
oleh faktor ekonomi, kesalahan dalam manajemen, dan bencana alam.

Analisis financial distress yang sering digunakan adalah Analisis Z-Score model Altman, model Springate dan model Zmijewski. Analisis tersebut dikenal karena selain caranya mudah, keakuratan dalam menentukan prediksi financial distress juga cukup akurat (Peter \& Yoseph, 2011). Dalam penelitian ini hanya menggunakan metode Zmijewski.

Metode Zmijewski X-Score adalah metode dengan menggunakan analisis rasio yang mengukur kinerja, leverage, dan likuiditas suatu perusahaa (Zmijewski, 1984). Rasio keuangan yang digunakan adalah rasio - rasio kelompok, rate of return, liquidity, leverage, turnover, fixed payment coverage, trends, firm size, dan stock return volatility, menunjukan adanya perbedaan yang signifikan antara perusahaan yang sehat dan yang tidak sehat (Peter \& Yoseph, 2011)

Penelitian menggunakan metode Zmijewski dalam menganalisis Financial Distress sudah banyak dilakukan. Penelitian yang dilakukan oleh Qisthi dan Handayani (2013) dengan hasil penelitian menunjukkan bahwa dari 8 perusahaan otomotif dan komponennya yang dijadikan sampel, 25\% dinyatakan terdapat indikasi-indikasi kebangkrutan, $75 \%$ merupakan perusahaan yang kondisinya berubah-ubah selama tiga tahun, dan tidak ditemukan perusahaan dengan kondisi sehat selama periode 3 tahun berturut-turut.

Yuliastary dan Wirakusuma (2014) dengan hasil penelitian menunjukkan bahwa kinerja keuangan pada PT Fast Indonesia Tbk periode 2008-2012 diklasifikasikan dalam keadaan sehat dan tidak berpotensi bangkrut.

Hasil dari penelitian Qisthi dan Handayani (2013), membuktikan bahwa dari 8 perusahaan otomotif dan komponennya yang dijadikan sampel, 25\% dinyatakan terdapat indikasi-indikasi kebangkrutan baik dalam kondisi buruk maupun rawan, $75 \%$ merupakan perusahaan yang kondisinya berubah-ubah selama tiga tahun, dan tidak ditemukan perusahaan dengan kondisi sehat selama periode 3 tahun berturut-turut.
Fatmawati (2012) yang meneliti tentang keakuratan metode Zmijewski, Altman dan Springate prediktor delisting. Hasil analisis menunjukkan bahwa model Zmijewski lebih akurat dalam memprediksi perusahaan delisting, dibandingkan dengan model Altman dan model Springate. Hal ini karena model Zmijewski lebih menekankan besarnya utang dalam memprediksi delisting.

Adanya perbedaan hasil penelitian dan bukti keakuratan metode Zmijewski dalam memprediksi kebangkrutan maka mendorong penulis untuk meneliti kembali dalam memprediksi kebangkrutan dengan metode Zmijewski XScore.

\section{Tinjauan Pustaka}

\subsection{Analisis Rasio Keuangan}

Rasio merupakan alat ukur yang digunakan perusahaan untuk menganalisis laporan keuangan. Rasio menggambarkan suatu hubungan atau pertimbangan antara suatu jumlah tertentu dengan jumlah yang lain. Menurut Riyanto (2001), analisis rasio keuangan adalah proses penentuan operasi yang penting dan karakteristik keuangan dari sebuah perusahaan dari data akuntansi dan laporan keuangan. Tujuan dari analisis ini adalah untuk menentukan efisiensi kinerja dari manajer perusahaan yang diwujudkan dalam catatan keuangan dan laporan keuangan. Rasio-rasio yang digunakan dalam metode Altman ini dapat dikelompokkan dalam tiga kelompok besar yaitu rasio likuiditas, rasio profitabilitas, rasio aktivitas dan rasio solvabilitas.

\subsection{Financial Distress}

Menurut Brigham dan Gapenski Financial distres atau kesulitan keuangan dimulai ketika perusahaan tidak dapat memenuhi jadwal pembayaran atau ketika proyeksi arus kas mengindikasikan bahwa perusahaan tersebut akan segera tidak dapat memenuhi kewajibannya (Fachrudin, 2008). Financial distress dibagi menjadi menjadi beberapa tipe yaitu economic failure, business failure, technical insolvency, insolvency in bankruptcy, dan legal bankruptcy. Financial distress terjadi sebelum kebangkrutan. 
Menurut Hanafi dan Halim (2012) kebangkrutan yang terjadi sebenarnya dapat diprediksi dengan melihat beberapa indikator-indikator, yaitu :

1. Analisis aliran kas untuk saat ini atau masa mendatang.

2. Analisis strategi perusahaan, yaitu analisis yang memfokuskan pada persaingan yang dihadapi oleh perusahaan.

3. Struktur biaya relatif terhadap pesaingnya.

4. Kualitas manajemen.

5. Kemampuan manajemen dalam mengendalikan biaya.

\subsection{Metode Zmijewski $X$-Score}

Dalam metode Zmijewski rasio keuangan yang digunakan adalah rasio - rasio kelompok, Rate of Return, liquidity, leverage, turnover, fixed payment coverage, trends, firm size, dan stock return volatility. Hasil penelitiannya menunjukan adanya perbedaan yang signifikan antara perusahaan yang sehat dan yang tidak sehat. Berikut model persamaan yang berhasil dikembangkan Zmijewski:

$$
X=-4,34,5 X_{1}+5,7 X_{2}+0,004 X_{3}
$$

(Rahayu, Suwendra \& Yulianthini, 2016).

Keterangan

$\mathrm{X}_{1}=$ Return on Asset atau Return on Investment

$\mathrm{X}_{2}=$ Debt Ratio

$\mathrm{X}_{3}=$ Current Ratio

Perusahaan yang mempunyai nilai $\mathrm{X}>0$ diprediksi mengalami Financial Distress. Sebaliknya, perusahaan yang nilai $\mathrm{X}<0$ atau negatif diprediksi tidak akan mengalami Financial Distress.

Berdasarkan uraian diatas maka dapat dirumuskan hipotesis:

$\mathrm{H}_{1}$ : Diprediksi terdapat perusahaan yang mengalami financial distres dengan analisis metode Zmijewski X-Score.

Adapun kerangka pemikiran sebagaimana Gambar 1.

\section{Metode Penelitian}

Penelitian ini merupakan penelitian eksplanatory bersifat cross-sectional dan time series atau disebut data panel (data pooled). Teknik

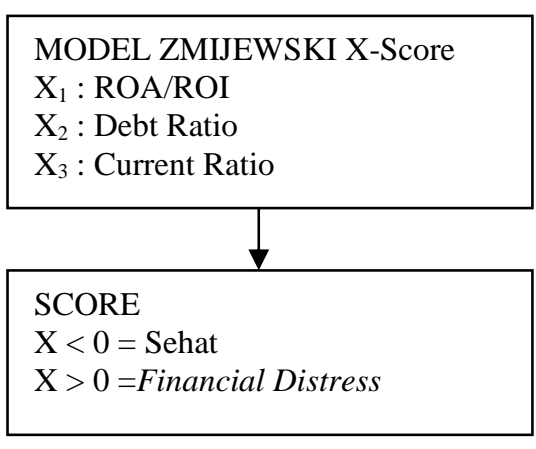

Gambar 1. Skema Kerangka Pemikiran penentuan sampel dalam penelitian ini adalah secara purposive sampling dengan kriteria yang digunakan untuk memilih sampel adalah perusahaan go publik yang masuk Sub Sektor Otomotif dan Komponen selama periode 2012-2016.

a. Perusahaan mempublikasikan laporan keuangan tahunan untuk periode 31 Desember 2012-2016 yang dinyatakan dalam rupiah (Rp).

b. Data perusahaan terkait penelitian tersedia lengkap.

Metode pengumpulan data adalah metode dokumenter yaitu data sekunder dalam bentuk laporan keuangan perusahaan_melalui laman www.idx.go.id.

Metode analisis data menggunakan analisis kuantitatif deskriptif yaitu untuk memprediksi terjadinya financial distress menggunakan metode Zmijewski X-Score. Metode deskriptif adalah metode yang mampu menjelaskan rumusan masalah yang berkenaan dengan pertanyaan terhadap variabel mandiri, baik hanya satu variabel atau lebih (Sugiyono, 2013).

Tahapan yang dilakukan dengan metode Zmijewski X-Score yaitu :

a. Menghitung rasio keuangan pada model Zmijewski X-Score, yaitu:

1) $\operatorname{ROA}\left(X_{1}\right)$

2) Debt Ratio $\left(\mathrm{X}_{2}\right)$

3) Current Ratio $\left(X_{3}\right)$

b. Melakukan perhitungan dengan analisis diskriminan yang ditemukan Zmijewski melalui rumus

$$
X=-4.3-4.5 X 1+5,7 \times 2+0.004 X 3
$$

Dimana:

$\mathrm{X}$-Score bernilai $<0$ atau negatif berarti perusahaan dalam kondisi sehat 
X-Score bernilai > 0 atau positif berarti perusahaan dalam kondisi finansial distress (Rahayu, et al., 2016).

\section{Hasil dan Pembahasan}

\subsection{Hasil penelitian}

Berdasarkan kriteria pemilihan sampel penelitian maka jumlah perusahaan yang menjadi sampel sebanyak 64 dari 65 perusahaan karena satu perusahaan yang datanya tidak lengkap yaitu BOLT pada tahun 2012.

\section{Metode Zmijewski X-Score}

Metode Zmijewiski menggunakan perhitungan X-Score sebagai berikut :

$\mathrm{X}$-Score $=-4,3-4,5 \mathrm{X} 1+5,7 \mathrm{X} 2+0,004 \mathrm{X} 3$

Dari tabel 5.2 menunjukkan bahwa pada tahun 2012 dan 2014 diprediksi semua keuangan perusahaan dalam kondisi sehat karena nilai XScorenya $<0$ atau negatif. Hasil analisis tahun 2013 diperoleh hasil hanya satu perusahaan yang diprediksi masuk kategori financial distress yaitu PT Garuda Metalindo Tbk dengan nilai sebesar 0,84 . Sedangkan tahun 2015 terdeteksi 1 perusahaan yang mengalami financial distress yaitu PT Indo Mobil Internasional Tbk karena mempunyai nilai 0,04 . Sedangkan pada tahn 2016 adalah PT Indo Mobil Internasional Tbk. mempunyai X-Score 0,45 dan PT Multi Prima
Sejahtera Tbk mempunyai nilai sebesar 1,23. Hasil analisis nilai rata-rata selama tahu 20122016 semua perusahaan mempunyai nilai XScore negatif hal ini berarti bahwa semua perusahaan dalam kondisi sehat.

\subsection{Pembahasan}

Dari hasil analisis metode Zmijewiski pada tahun 2012 (Tabel 1) terdeteksi tidak ada perusahaan yang keuangannya dalam kondisi financial distress karena nilai X-Scorenya $<0$ atau bernilai negatif, hal ini berarti bahwa semua keuangan perusahaan dalam kondisi sehat. Hal ini mengindikaskan bahwa dalam tahun 2012 perusahaan-perusahaanpada sub sektor otomotif dan komponen dalam mengelola keuangannya sudah baik. Hasil ini mendukung hasil penelitian dari Kuncoro (2013) dengan hasil bahwa PT. Beton Jaya Manunggal Tbk. menggunakan model analisis Zmijewski mengidentifikasikan perusahaan dalam kondisi sehat.

Tahun 2013 diperoleh hasil metode X-Score dari jumlah 13 perusahaan hanya satu perusahaan yang masuk kategori financial distress yaitu PT Garuda Metalindo Tbk dengan nilai 0,84>0 sedangkan 12 perusahaan lainnya terdeteksi dalam kondisi sehat. Dalam tahun ini PT Garuda

Tabel 1. Hasil Analisis model X-Score tahun 2012-2016

\begin{tabular}{lllllll}
\hline \multicolumn{1}{c}{ Kode } & \multicolumn{7}{c}{ Nilai X-Score } & Rata- \\
Perush. & 2012 & 2013 & 2014 & 2015 & 2016 & rata \\
\hline ASII & $-1,93$ & $-1,94$ & $-1,91$ & $-1,87$ & $-1,93$ & $-1,92$ \\
AUTO & $-2,67$ & $-3,23$ & $-2,94$ & $-2,73$ & $-2,67$ & $-2,85$ \\
BOLT & 0,0 & 0,84 & $-3,39$ & $-3,85$ & $-3,98$ & $-2,08$ \\
BRAM & $-3,57$ & $-2,51$ & $-2,17$ & $-2,36$ & $-2,64$ & $-2,65$ \\
GDYR & $-1,32$ & $-1,63$ & $-1,88$ & $-0,56$ & $-0,97$ & $-1,27$ \\
GJTL & $-1,40$ & $-0,73$ & $-0,63$ & $-0,27$ & $-0,55$ & $-0,72$ \\
IMAS & $-0,64$ & $-0,49$ & $-0,29$ & 0,04 & 0,45 & $-0,19$ \\
INDS & $-2,83$ & $-4,45$ & $-3,37$ & $-3,09$ & $-3,41$ & $-3,43$ \\
LPIN & $-3,48$ & $-2,87$ & $-2,48$ & $-0,42$ & 1,23 & $-1,61$ \\
MASA & $-2,28$ & $-2,06$ & $-1,97$ & $-1,68$ & $-1,74$ & $-1,95$ \\
NIPS & $-1,11$ & $-0,43$ & $-1,78$ & $-0,91$ & $-1,47$ & $-1,14$ \\
PRAS & $-1,70$ & $-2,00$ & $-2,02$ & $-1,41$ & $-1,70$ & $-1,77$ \\
SMSM & $-2,70$ & $-2,80$ & $-3,27$ & $-3,20$ & $-3,02$ & $-3,00$ \\
TOTAL & $-1,97$ & $-1,87$ & $-2,16$ & $-1,72$ & $-1,72$ & $-1,89$ \\
\hline
\end{tabular}


Metalindo Tbk dalam mengelola keuangannya kurang baik dan harus lebih berhati-hati lagi supaya tidak sampai terjadi hal yang lebih buruk lagi yaitu kebangkrutan, yaitu dengan mengurangi utang perusahaan . 12 perusahaan lainnya dalam mengelola keuangan perusahaan sudah baik dan harus bisa mempertahankan kinerja keuangan pada tahun selanjutnya. Hasil ini sejalan dengan hasil penelitian Rahayu, et al. (2016) yang membuktikan bahwa perusahaan telekomunikasi dengan metode Zmijewski tidak diklasifikasikan tidak mengalami financial distress sepanjang periode 2012-2013.

Hasil analisis tahun 2014 sama dengan hasil analisis tahun 2012 yaitu bahwa tidak ada perusahaan yang diprediksi kondisi keuangannya dalam mengalami financial distress karena nilai $\mathrm{X}$-Scorenya $<0$ atau bernilai negatif, hal ini menunjukkan bahwa semua keuangan perusahaan dalam kondisi sehat. Pada tahun 2014 keadaan sama dengan pada tahun 2012 dimana perusahaan pada perusahaan sub sektor otomotif dan komponen mempunyai kinerja keuangan yang sudah bagus. Penelitian mendukung hasil penelitian dari Kuncoro (2013) membuktikan bahwa PT. Beton Jaya Manunggal Tbk. Menggunakan model Zmijewski diidentifikasi kondisi keuangan perusahaan dalam kondisi sehat.

Tahun 2015 menunjukkan bahwa terdapat satu perusahaan yang diprediksi mengalami financial distress yaitu PT Indo Mobil Internasional Tbk karena mempunyai nilai X-Score $>0$ yaitu sebesar 0,04. Sedangkan 12 perusahaan lainnya X-Scorenya bernilai negatif atau kurang dari nol maka disimpulkan bahwa 12 perusahaan tersebut dalam kondisi sehat. Pada tahun ini PT Indo Mobil Internasional Tbk harus berhati-hati karena kondisi keuangan perusahaan tidak baik dan harus segera memperbaiki kondisi keuangan perusahaan seperti dengan meningkatkan likuiditas perusahaan. Hasil penelitian yang sama sudah dilakukan asil penelitian sebelumnya Qisthi dan Handayani (2013), yang menyatakan bahwa diprediksi ada sekitar $25 \%$ perusahaan sampel yang mengalami financial distress.
Sedangkan pada tahun 2016 PT Indo Mobil Internasional Tbk mempunyai X-Score positif sebesar 0,45 dan PT Multi Prima Sejahtera Tbk sebesar 1,23 berarti mengindikasikan bahwa kondisi keuangan kedua perusahaan tersebut mengalami financial distress. Perusahaan yang lainnya sebanyak 11 perusahaan mempunyai nilai X-Score negatif, hal ini berarti perusahaanperusahaan tersebut dalam kondisi sehat. Dua perusahaan yaitu PT Indo Mobil Internasional Tbk dalam meningkatkan kondisi keuangan perusahaan dengan meningkatkan profit perusahaan mengingat nilai ROAnya negatif dan menurunkan utang perusahaan, sedangkan PT Multi Prima Sejahtera Tbk harus berhati-hati dan lebih meningkatkan kinerja keuangannya dengan meningkatkan profitabilitas perusahaan karena nilai ROAnya negatif. supaya kondisi keuangan perusahaan menjadi lebih baik. Sedangkan 11 perusahaan lain sudah baik dalam mengelolan keuangan perusahaan. Hasil ini juga mendukung hasil penelitian Qisthi dan Handayani (2013).

Dari hasil analisis dengan metode Zmijewiski X-Score dalam kurun waktu tahun 2012 sampai tahun 2016 diprediksi terdapat 3 perusahaan yang mengalami financial distress yaitu PT Garuda Metalindo. Tbk, PT Indo Mobil Internasional Tbk dan PT Multi Prima Sejahtera Tbk terbukti dengan nilai X-Score lebih besar dari 0 atau positif. Sedangkan 10 perusahaan lainnya setahun 2012-2016 diprediksi keuangan perusahaan dalam kondisi sehat atau baik karena selalu mempunyai nilai X-Score lebih kecil dari nol atau negatif. Ketiga perushaan harus melakukan evaluasi dan perbaikan kinerja keuangannya supaya menjadi sehat dan dapat bersaing terus dengan perusahaan-perusahaan pesaingnya. Kondisi financial distress dapat terjadi karena persaingan eksport produk otomotif dan komponen dari negara-negara lain seperti China, semakin mahalnya bea masuk dan kesulitan dalam mendapatkan bahan baku, bahan penunjang di bidang otomotif dan komponen.

Dari hasil penelitian ini menunjukkan bahwa terdapat $23 \%$ perusahaan yang diprediksi mengalami financial distress dan $77 \%$ perusahaan 
diprediksi kondisi keuangannya sehat. Hasil penelitian ini mendukung hasil penelitian sebelumnya Qisthi dan Handayani (2013), yang menyatakan bahwa diprediksi ada sekitar $25 \%$ perusahaan sampel yang mengalami financial distress.

Dari hasil analisis jika dibuat rata-rata nilainya dari tahun 2012-2016 menunjukkan bahwa semua perusahaan kondisi keuangannya sehat atau baik karena semua perusahaan mempunai nilai rata-rata X-Score lebih kecil dari nol atau negatif. Hal ini menunjukkan bahwa selama kurun waktu lima tahun perusahaanperusahaan pada sub sektor otomotif dan komponen manajemen dalam mengelola keuangan perusahaan sudah baik. Hasil ini mendukung penelitian yang sudah dilakukan oleh Yuliastary dan Wirakusuma (2014) dengan hasil penelitian menunjukkan bahwa kinerja keuangan pada PT Fast Indonesia Tbk periode 2008-2012 diklasifikasikan dalam keadaan sehat dan tidak berpotensi bangkrut.

\section{Kesimpulan}

Berdasarkan hasil analisis dan uji data serta pembahasan, maka dapat ditarik kesimpulan bahwa analisis dengan metode Zmijewiski XScore menunjukkan bahwa dari tahun 2012-2016 terdeteksi 3 perusahaan yang mengalami financial distress yaitu PT Garuda Metalindo. Tbk, PT Indo Mobil Internasional Tbk dan PT Multi Prima Sejahtera Tbk. Sedangkan dari nilai ratarata selama 5 tahun semua perusahaan mempunyai nilai $<0$ atau negatif maka hal ini berarti semua perusahaan dalam kondisi sehat.

Bagi Manajer perusahaan dalam mengelola keuangan perusahaan harus lebih efektif dan efisien sehingga perusahaan tidak sampai mengalami kesulitan keuangan (financial distress). Bagi para investor dapat digunakan sebagai rujukan dalam pengambilan keputusan untuk berinvestasi dengan melihat perusahaan yang menunjukkan perusahaan yang memiliki kinerja keuangan baik.Bagi peneliti selanjutnya sebaiknya meneliti pada perusahaan di sektor lainnya di sektor properti, perbankan atau peru- sahaan pada indek syariah maupun indeks konvensional, disamping itu juga menggunakan metode yang lain seperti Springeti atau metode Olhson dan Grover.

\section{Ucapan Terimakasih}

Ucapan terimakasih kepada DRPM Kemenristek Dikti yang telah memberikan dana hibah melalui skim Penelitian Dosen Pemula.

\section{Daftar Pustaka}

Fachrudin, K.A. (2008). Kesulitan Keuangan Perusahaan dan Pesonal. Medan: Usu Press.

Fatmawati, M. (2012). Penggunaan the Zmijewski Model, the Altman Model, dan the Springate Model sebagai prediktor delisting. Jurnal Keuangan dan Perbankan, 16(1).

Hanafi, M. M, \& Halim, A. (2012). Analisis Laporan Keuangan, Edisi Keempat.Yogyakarta:UPP AMP YKPN.

Kuncoro, A. W. (2013). Analisis Kebangkrutan Dengan Metode Springate Dan Zmijewski Pada Pt. Betonjaya Manunggal Tbk Periode 2007-2011. Jurnal Ekonomika dan Manajemen, 2(1).

Peter, P., \& Yoseph, Y. (2011). Analisis Kebangkrutan dengan Metode Z-score Altman, Springate dan Zmijewski pada PT. Indofood Sukses Makmur Tbk Periode 2005-2009. Maksi, 4(2).

Qisthi, D., \& Handayani, S. R. (2013). Analisis X-score (Model Zmijewski) Untuk Memprediksi Gejala Kebangkrutan Perusahaan (Pada Industri Otomotif Dan Komponennya Yang Terdaftar Di Bei Periode 2009-2011). Jurnal Administrasi Bisnis, 1(2), 68-77.

Rahayu, F., Suwendra, I. W., \& Yulianthini, N. N.(2016). Analisis financial distress dengan menggunakan metode Altman Z-Score, Springate, dan Zmijewski pada perusahaan telekomunikasi. Jurnal

Jurusan Manajemen, 4(1).

Riyanto, B. (2001). Dasar-Dasar Pembelanjaan Perusahaan. Yogyakarta: BPFE. 
Jurnal Akuntansi dan Pajak, 19(02), 2019, 140

Sudana, I. M. (2011). Manajemen Keuangan Perusahaan Teori dan Praktik. Jakarta: Erlangga.

Sugiyono. (2013). Metode Penelitian Pendidikan (Pendekatan Kuantitatif, Kualitatif, dan $R \& D)$. Bandung: Alfabeta.

Warta Ekonomi, (2018). Industri Komponen Otomotif Masih Net Importer. Online https://www.wartaekonomi.co.id/read18489 7/industri-komponen-otomotif-masih-net- importer.html. Diakses pada tanggal 10 Agustus 2018.

Yuliastary, E. C., \& Wirakusuma, M. G. (2014). Analisis Financial Distress dengan Metode Z-Score Altman, Springate, Zmijewski. EJurnal Akuntansi, 379-389.

Zmijewski, ME. (1984). Methodological Issues Related to The Estimation of Financial Distress Model.Journal of Accounting Research, p59-82 